\title{
Sintering Characteristic, Structure, Microwave Dielectric Properties and Compatibility with Ag of Novel 3MgO-B2O3-xwt\% Ba(CuB2)05-ywt\% H3BO3 Ceramics
}

\section{Haiquan WANG}

Guilin University of Technology

Shixuan LI

Guilin University of Technology

Kangguo WANG

Guilin University of Technology

\section{Xi WANG}

Guilin University of Technology

Hailin ZHANG

Guilin University of Technology

\section{You WU}

Guilin University of Technology

\section{Xiuli CHEN}

Guilin University of Technology

Huanfu Zhou ( $\nabla$ zhouhuanfu@163.com )

Guilin University of Technology

\section{Research Article}

Keywords: ceramics, Mg3B2O6, H3BO3, BCB, microwave dielectric properties

Posted Date: August 24th, 2021

DOl: https://doi.org/10.21203/rs.3.rs-832397/v1

License: (9) This work is licensed under a Creative Commons Attribution 4.0 International License. Read Full License 


\section{Abstract}

In this study, $3 \mathrm{MgO}-\mathrm{B}_{2} \mathrm{O}_{3}-x w t \% \mathrm{BCB}-y w t \% \mathrm{H}_{3} \mathrm{BO}_{3}(2 \leq x \leq 8,0 \leq y \leq 20)$ ceramics were sintered at the optimum temperature to form $\mathrm{Mg}_{3} \mathrm{~B}_{2} \mathrm{O}_{6}$ and $\mathrm{MgO}$ phases. The effects of $\mathrm{H}_{3} \mathrm{BO}_{3}$ and $\mathrm{BCB}$ on product characteristics, phase transition, microstructure, and microwave properties of $3 \mathrm{Mg}-\mathrm{B}_{2} \mathrm{O}_{3}$ ceramics were investigated. The intensities of diffraction peaks of two phases varied with changing the $x$ and $y$ values. After sintering at $950^{\circ} \mathrm{C}$, the ceramics with $x=6$ and $y=15$ achieved excellent microwave properties with a $\varepsilon_{r}$ of $6.72, Q \times f$ of $83205 \mathrm{GHz}$, and $\tau_{f}$ of $-65.05 \mathrm{ppm} /{ }^{\circ} \mathrm{C}$. Besides, the ceramic with $x=8$ and $y=5$ sintered at $925^{\circ} \mathrm{C}$ also achieved good microwave dielectric properties with a $\varepsilon_{r}$ of $6.64, Q \times f$ of 78173 $\mathrm{GHz}$, and $\tau_{f}$ of $-57.27 \mathrm{ppm} /{ }^{\circ} \mathrm{C}$. The sintering temperatures of above both ceramics are well lower than the melting point of $\mathrm{Ag}$, showing promising applications in low temperature cofired ceramic devices. In particular, these two ceramics can be used as potential candidate materials for microwave ceramics for $5 \mathrm{G}$ technology, provided that $\tau_{f}$ can be further optimized.

\section{Introduction}

In recent years, LTCC technology is widely used in microwave circuits manufacturing and has become the research hot topic for passive component integration [1-7]. In particular, with the emergence of $5 \mathrm{G}$ largescale antenna (Massive MIMO) technology, the number of antennas will increase exponentially. The demand of filters for signal frequency selection and processing will grow with the passage of time, thus the demand for low-temperature co-fired ceramics (LTCC) will also increase significantly [8-13]. LTCC technology requires the dielectrics cofire with high conductivity material electrodes. Because of the low melting point of electrodes (e.g., Ag melting point: $961^{\circ} \mathrm{C}$, Al melting point: $660^{\circ} \mathrm{C}$ ), microwave dielectric materials is desired to have low sintering temperatures [14-17].

In the $\mathrm{MgO}-\mathrm{B}_{2} \mathrm{O}_{3}$ system, Zhou et al [18-20] reported that the sintering temperatures of $\mathrm{MgO}-\chi \mathrm{B}_{2} \mathrm{O}_{3}$ ceramics could be reduced by adding $\mathrm{BaCu}\left(\mathrm{B}_{2} \mathrm{O}_{5}\right)(\mathrm{BCB})$. MgO- $2 \mathrm{~B}_{2} \mathrm{O}_{3}-4 \mathrm{wt} \% \mathrm{BCB}$ ceramics manufactured at $925^{\circ} \mathrm{C}$ have excellent microwave properties and is a candidate for $\mathrm{LTCC}$ components. Based on the above research, they found that $\mathrm{MgO}-2 \mathrm{~B}_{2} \mathrm{O}_{3}-40 \mathrm{wt} \% \mathrm{H}_{3} \mathrm{BO}_{3}-4 \mathrm{wt} \% \mathrm{BCB}$ and $\mathrm{MgO}-2 \mathrm{~B}_{2} \mathrm{O}_{3}-10 \mathrm{wt} \% \mathrm{H}_{3} \mathrm{BO}_{3^{-}}$ $4 \mathrm{wt} \% \mathrm{BCB}$ manufactured at $900^{\circ} \mathrm{C}$ and $925^{\circ} \mathrm{C}$ also had excellent microwave dielectric properties. MgO-rich $3 \mathrm{MgO}-\mathrm{B}_{2} \mathrm{O}_{3}$ ceramics with good microwave properties have also been of interest to scholars. Dosler reported that $\mathrm{Mg}_{3} \mathrm{~B}_{2} \mathrm{O}_{6}$ ceramics with a grain size of $1000 \mu \mathrm{m}$ could reach $Q \times f$ values up to more than $220,000 \mathrm{GHz}$ [21]. Gu et al. [22] found that pure phase $\mathrm{Mg}_{3} \mathrm{~B}_{2} \mathrm{O}_{6}$ ceramic could be obtained when the $\mathrm{Mg} / \mathrm{B}$ molar ratio is 1.2. An appropriate excess of $\mathrm{MgO}$ could increase its $Q \times f$ value, but it did not contribute to its densification. Kan et al. [23] found that an appropriate amount of $\mathrm{B}_{2} \mathrm{O}_{3}$ doping effectively lowered the sintering temperature of this ceramic and improved the dielectric properties of $\mathrm{MgO}$ compound. As $x=0.99, x \mathrm{MgO}-(1-x) \mathrm{B}_{2} \mathrm{O}_{3}$ ceramic sintered at $1,350^{\circ} \mathrm{C}$ for 4 hours had a $Q \times f$ value of $773,300 \mathrm{GHz}$. Appropriate ion substitution has been reported to favor densification and dielectric properties of ceramics. For example, Gu et al. [24] found that $\left(\mathrm{Mg}_{0.8} \mathrm{Ca}_{0.2}\right)_{3} \mathrm{~B}_{2} \mathrm{O}_{6}$ ceramics manufactured 
at $1,250^{\circ} \mathrm{C}$ showed $\varepsilon_{r}=6.8, Q \times f=103556 \mathrm{GHz}$, and $\tau_{f}=-34.5 \mathrm{ppm} /{ }^{\circ} \mathrm{C}$. Furthermore, they [22] also reported the excellent microwave properties of $\left(\mathrm{Mg}_{0.998} \mathrm{Sr}_{0.002}\right)_{3} \mathrm{~B}_{2} \mathrm{O}_{6}$ ceramics sintered at $1250^{\circ} \mathrm{C}: \varepsilon_{r}=$ $6.9, Q \times f=110820 \mathrm{GHz}$, and $\tau_{f}=-32.4 \mathrm{ppm} /{ }^{\circ} \mathrm{C}$.

Though $3 \mathrm{MgO}-\mathrm{B}_{2} \mathrm{O}_{3}$ material system has high $Q \times f$ values, it is manufactured at high sintering temperatures, which not only hinder their incorporation with low melting electrode and polymer based substrates, but also lead to huge energy consumption and volatile components evaporation. Su et al [25] found that $\mathrm{Ni}^{2+}$ can be used as a substitute of $\mathrm{Zn}^{2+}$ to optimize the sintering behavior and microwave dielectric properties of $\mathrm{Zn}_{3} \mathrm{~B}_{2} \mathrm{O}_{6}$ ceramics. In addition, they [26] reported that a mixture of $\mathrm{Mg}_{3} \mathrm{~B}_{2} \mathrm{O}_{6}$ and $\mathrm{Zn}_{3} \mathrm{~B}_{2} \mathrm{O}_{6}$ was used to obtain ceramics with excellent dielectric properties at $950^{\circ} \mathrm{C}$. Dou et al. [27] investigated the excellent microwave dielectric properties in $\mathrm{Mg}_{3} \mathrm{~B}_{2} \mathrm{O}_{6}$ ceramics with $35 \%$ lithium magnesium borosilicate glass sintered at $950^{\circ} \mathrm{C}$ for $3 \mathrm{~h}: \varepsilon_{r}=6.5, Q \times f=21000 \mathrm{GHz}, \tau_{f}=-49.5 \mathrm{ppm} /{ }^{\circ} \mathrm{C}$. Hu et al. [28] found that $55 \mathrm{wt} \%$ lithium magnesium zinc borosilicate glass addition reduced the sintering temperature of $\mathrm{Mg}_{3} \mathrm{~B}_{2} \mathrm{O}_{6}$ ceramics to $\sim 950^{\circ} \mathrm{C}$ and achieve the excellent microwave dielectric properties with a $\varepsilon_{r}$ of $6.8, Q \times f$ of $50,000 \mathrm{GHz}$, and $\tau_{f}$ of $-64 \mathrm{ppm} /{ }^{\circ} \mathrm{C}$. Usually, materials (such as $\mathrm{H}_{3} \mathrm{BO}_{3}, \mathrm{CuO}$, and $\mathrm{V}_{2} \mathrm{O}_{5}$ ) with low melting point are often added to lower the sintering temperature for liquid-phase sintering to obtain dense sintered ceramics [29-33]. However, the microwave properties of ceramics doped with low melting point materials are usually much deteriorated $[16,33,34]$. The addition of $\mathrm{BaCu}\left(\mathrm{B}_{2} \mathrm{O}_{5}\right)(\mathrm{BCB})$ with low melting temperature, good wettability and microwave dielectric properties could contribute to the densification of $\mathrm{Mg}_{3} \mathrm{~B}_{2} \mathrm{O}_{6}$ ceramics [35-37]. However, it is difficult to obtain pure $\mathrm{Mg}_{3} \mathrm{~B}_{2} \mathrm{O}_{6}$ ceramics because high-temperature sintering will lead to the volatilization of $\mathrm{B}_{2} \mathrm{O}_{3}$ [22]. Although some studies have been reported, the relationship between structure and microwave properties of ceramics with addition of $\mathrm{BCB}$ and $\mathrm{H}_{3} \mathrm{BO}_{3}$ in $3 \mathrm{MgO}-\mathrm{B}_{2} \mathrm{O}_{3}$ needs to be further investigated.

In this study, a series of ceramics of $3 \mathrm{MgO}-\mathrm{B}_{2} \mathrm{O}_{3}$-xwt\%BCB-ywt $\mathrm{H}_{3} \mathrm{BO}_{3}$ (where $x=2,4,6,8 ; y=0,5,10,15$, 20) were prepared by a conventional solid-phase reaction method. The sintering behavior, microstructure, microwave dielectric properties and compatibility with Ag are reported in detail.

\section{Experimental}

$\mathrm{Mg}_{3} \mathrm{~B}_{2} \mathrm{O}_{6}$ ceramics were prepared by solid-phase method. The raw materials were $\mathrm{MgO}(>98.5 \%), \mathrm{H}_{3} \mathrm{BO}_{3}$ $(>99 \%), \mathrm{CuO}(>99 \%)$, and $\mathrm{Ba}(\mathrm{OH})_{2} \cdot 8 \mathrm{H}_{2} \mathrm{O}(>99 \%)$. All the raw materials were obtained from Sinopharm, Beijing, China. The $\mathrm{MgO}$ was calcined at $800{ }^{\circ} \mathrm{C}$ for $2 \mathrm{~h}$ to remove water and impurities. $\mathrm{Ba}(\mathrm{OH})_{2} \cdot 8 \mathrm{H}_{2} \mathrm{O}$ was sieved. The raw materials were ball milled with anhydrous ethanol as the medium for $4 \mathrm{~h}$, then dried and sieved. The mixtures were calcined at $800^{\circ} \mathrm{C}$ for $4 \mathrm{~h}$. The calcined powders mixed with predetermined amount of BCB were subjected to secondary ball milling. $5 w t \%$ Polyvinyl alcohol (PVA) was added as the binder to the pellet. The powders were pressed into cylindrical samples having a diameter of $10 \mathrm{~mm}$ and a height of $\sim 5 \mathrm{~mm}$ under $200 \mathrm{MPa}$. The resulted samples were sintered in air at $850{ }^{\circ} \mathrm{C}$ to $1050{ }^{\circ} \mathrm{C}$ for 4 h. 
An X-ray diffraction spectroscopy (Model X'Pert Pro, PANalytical, Almelo, Netherlands) was used for structure analysis of the specimens. The microstructure of the ceramic surfaces was observed with a scanning electron microscope (SEM, JSM6380-LV SEM, JEOL, Tokyo, Japan). The bulk density of the sintered samples was measured by Archimedes method. Microwave dielectric properties at microwave frequencies were measured using TE01 $\delta$ dielectric resonator method and network analyzer (E5071C, Agilent Co., CA, USA) over a frequency range of $300 \mathrm{kHz}$ to $20 \mathrm{GHz}$ at room temperature. $\tau_{f}$ values were obtained over a temperature range of $25^{\circ} \mathrm{C}$ to $85^{\circ} \mathrm{C}$ as shown below.

$$
\tau_{\mathrm{f}}=\frac{f_{T}-f_{T 0}}{f_{T 0}\left(T-T_{0}\right)} \times 10^{6}
$$

where, $f_{T}$ and $f_{T O}$ represent the resonant frequencies at $85^{\circ} \mathrm{C}(\mathrm{T})$ and $25^{\circ} \mathrm{C}\left(\mathrm{T}_{0}\right)$, respectively.

\section{Results And Discussion}

As shown in Fig. 1 , the XRD patterns of $3 \mathrm{MgO}-\mathrm{B}_{2} \mathrm{O}_{3}-x \mathrm{wt} \% \mathrm{BCB}(x=2,4,6,8 ; y=0)$ ceramics sintered at the optimum temperature. As $x$ increased from 2 to 8 , two major phases, indexed as $\mathrm{Mg}_{3} \mathrm{~B}_{2} \mathrm{O}_{6}$ (JCPDS: 751807) and $\mathrm{MgO}$, were detected. The diffraction peaks of $\mathrm{MgO}$ slowly decreased and that of $\mathrm{Mg}_{3} \mathrm{~B}_{2} \mathrm{O}_{6}$ gradually enhanced with the increase of $x$, which indicates that with the increase of BCB content, the decrease of sintering temperature and $\mathrm{B}_{2} \mathrm{O}_{3}$ volatilization will induce the increase of $\mathrm{Mg}_{3} \mathrm{~B}_{2} \mathrm{O}_{6}$ content and decrease of $\mathrm{MgO}$ content.

SEM images of $3 \mathrm{MgO}-\mathrm{B}_{2} \mathrm{O}_{3}$-xwt\%BCB $(x=2,4,6,8)$ ceramics with optimum sintering temperature are illustrated in Fig. 2. Dense microstructure was observed. The grains gradually became more homogeneous and denser as $x$-value increased. The average grain sizes of the ceramics are approximately $1.88 \mu \mathrm{m}\left(x=2,1050^{\circ} \mathrm{C}\right), 2.07 \mu \mathrm{m}\left(x=4,1025^{\circ} \mathrm{C}\right), 1.53 \mu \mathrm{m}\left(x=6,975^{\circ} \mathrm{C}\right)$ and $1.81 \mu \mathrm{m}(x=$ $\left.8,950^{\circ} \mathrm{C}\right)$. In particular, $3 \mathrm{MgO}-\mathrm{B}_{2} \mathrm{O}_{3}-6 \mathrm{wt} \% \mathrm{BCB}$ showed variable grain growth and finer grains at $975^{\circ} \mathrm{C}$. This indicates that the addition of appropriate $\mathrm{BCB}$ sintering aids can refine the grains. In addition, the sintering temperature of $3 \mathrm{MgO}-\mathrm{B}_{2} \mathrm{O}_{3}-x w t \% B C B(x=2,4,6,8)$ ceramics gradually decreased with the increase of $x$ value. A grain boundary melting phenomenon appeared in $3 \mathrm{MgO}-\mathrm{B}_{2} \mathrm{O}_{3}-8 \mathrm{wt} \% \mathrm{BCB}$, indicating the critical role played by BCB as a sintering aid.

The variation curves of $\rho, \varepsilon_{n} Q x f$ and $\tau_{f}$ of $3 \mathrm{MgO}-\mathrm{B}_{2} \mathrm{O}_{3}$-xwt\%BCB $(x=2,4,6,8)$ ceramics at different sintering temperature are shown in Fig. 3. As shown in Figs. 3 (a) and (c), the bulk density first increased slightly and then decreased with the increase of the sintering temperature. With changing the sintering temperature, the variation of $\varepsilon_{r}$ is consistent with that of bulk density. The higher the bulk density is, the higher the permittivity is. As $x$ value increased from 2 to 8 , the bulk density increased but the value of $\varepsilon_{r}$ decreased, which may be attributed to the addition of BCB with a low $\varepsilon_{r}\left(\varepsilon_{r} \sim 7.4\right)$ [35]. 
The change of $Q x f$ with sintering temperature for $3 \mathrm{MgO}-\mathrm{B}_{2} \mathrm{O}_{3}-x \mathrm{wt} \% \mathrm{BCB}(x=2,4,6,8)$ ceramics is similar to that of bulk density, as shown in Fig. 3(d). The $Q \times f$ is mainly affected by ceramic densification. Higher density leads to a lower porosity and lower losses. A moderate particle size is associated with higher quality factors and lower grain boundary losses [38]. However, desired moderate particle size cannot be obtained for ceramics at lower sintering temperatures. The bulk density of samples first increased and then decreased with the increase of $x$, indicating that the addition of appropriate amounts of BCB not only decreased the sintering temperature of ceramics but also resulted in denser ceramic, which are consistent with the analysis of the SEM images, as shown in Fig. 2. The $Q \times f$ values of $3 \mathrm{MgO}-\mathrm{B}_{2} \mathrm{O}_{3}-$ $x w t \% B C B(x=2,4,6,8)$ ceramics initially increased to the maximum and then decreased. The optimum sintering temperature gradually decreased as the $x$ increased from 2 to 8 . The optimum $Q x f$ increased from $73,674 \mathrm{GHz}$ to $99,008 \mathrm{GHz}$. With further increase of BCB content, the $Q x f$ decreased to $75,222 \mathrm{GHz}$. The first increase and then decrease of $Q \times f$ can be ascribed to the deterioration of quality factor of $3 \mathrm{MgO}$ $\mathrm{B}_{2} \mathrm{O}_{3}$ by the addition of excess $\mathrm{BCB}$.

The 3MgO- $\mathrm{B}_{2} \mathrm{O}_{3}-x \mathrm{wt} \% \mathrm{BCB}(x=2,4,6,8)$ ceramics showed good overall performance: $\varepsilon_{r}=6.64-7.36, Q x f$ $=73,674-99,008 \mathrm{GHz}, \tau_{f}=-73.01$ to $-59.38 \mathrm{ppm} /{ }^{\circ} \mathrm{C}$. BCB addition could reduce the sintering temperature of $3 \mathrm{MgO}-\mathrm{B}_{2} \mathrm{O}_{3}$ ceramics from $1,050^{\circ} \mathrm{C}$ to $950^{\circ} \mathrm{C}$. Notably, $3 \mathrm{MgO}-\mathrm{B}_{2} \mathrm{O}_{3}-4 \mathrm{wt} \% \mathrm{BCB}$ ceramics sintered at $1,025^{\circ} \mathrm{C}$ for $4 \mathrm{~h}$ exhibited excellent microwave dielectric properties with a $\varepsilon_{r}$ of 7.36, a $Q \times f$ of $99,008 \mathrm{GHz}$, and a $\tau_{f}$ of $-59.38 \mathrm{ppm} /{ }^{\circ} \mathrm{C}$. The $3 \mathrm{MgO}-\mathrm{B}_{2} \mathrm{O}_{3}-8 \mathrm{wt} \% \mathrm{BCB}$ ceramic sintered at $950^{\circ} \mathrm{C}$ for $4 \mathrm{~h}$ also exhibited excellent microwave properties with a $\varepsilon_{r}$ of 6.64 , a $Q \times f$ of $75222 \mathrm{GHz}$, and a $\tau_{f}$ of $-64.92 \mathrm{ppm} /{ }^{\circ} \mathrm{C}$.

Figure 4 exhibits the room-temperature XRD patterns of $3 \mathrm{MgO}-\mathrm{B}_{2} \mathrm{O}_{3}-2 \mathrm{wt} \% \mathrm{BCB}-y \mathrm{wt} \% \mathrm{H}_{3} \mathrm{BO}_{3}(y=0,5,10$, 15 , and 20) ceramics sintered at their optimum temperatures. The constituent phases of the ceramics are $\mathrm{Mg}_{3} \mathrm{~B}_{2} \mathrm{O}_{6}$ (PDF:038-1475) and $\mathrm{MgO}$ complex phases. However, the diffraction peaks of $\mathrm{MgO}$ decreased and that of $\mathrm{Mg}_{3} \mathrm{~B}_{2} \mathrm{O}_{6}$ phase increased with the increase of $y$, indicating that the increase in $\mathrm{H}_{3} \mathrm{BO}_{3}$ content not only decreased the sintering temperature but also compensated the boron content of $3 \mathrm{MgO}-\mathrm{B}_{2} \mathrm{O}_{3}$ ceramics. Therefore, the content of $\mathrm{Mg}_{3} \mathrm{~B}_{2} \mathrm{O}_{6}$ phase gradually increased, while the content of $\mathrm{MgO}$ phase gradually decreased, thereby directly affecting the microwave dielectric properties of $3 \mathrm{MgO}-\mathrm{B}_{2} \mathrm{O}_{3}$ $2 \mathrm{wt} \% \mathrm{BCB}-\mathrm{ywt} \% \mathrm{H}_{3} \mathrm{BO}_{3}(y=0,5,10,15$, and 20$)$.

Figure 5 shows the SEM and grain size distribution of $3 \mathrm{MgO}-\mathrm{B}_{2} \mathrm{O}_{3}-2 \mathrm{wt} \% \mathrm{BCB}-y \mathrm{wt} \% \mathrm{H}_{3} \mathrm{BO}_{3}(y=0,5,10,15$ and 20) ceramics sintered at their optimum temperatures. The images show that the average grain sizes of the ceramics were approximately $1.93 \mu \mathrm{m}(y=0), 1.64 \mu \mathrm{m}(y=5), 2.47 \mu \mathrm{m}(y=10), 1.9 \mu \mathrm{m}(y=15)$, and $2.03 \mu \mathrm{m}(y=20)$. In particular, the porosity of the ceramic samples became smaller with the increase of $\mathrm{H}_{3} \mathrm{BO}_{3}$. The comparison of the grain size of ceramics without and with $\mathrm{H}_{3} \mathrm{BO}_{3}$ shows that $\mathrm{H}_{3} \mathrm{BO}_{3}$ had an influence on the growth behaviour of this ceramics, showing that the appropriate amount of $\mathrm{H}_{3} \mathrm{BO}_{3}$ chould promote the growth of ceramics. The optimum sintering temperatures of ceramics gradually decreased with the increase of $y$. The optimum sintering temperatures were $1050^{\circ} \mathrm{C}, 1025^{\circ} \mathrm{C}, 1000^{\circ} \mathrm{C}$, $975^{\circ} \mathrm{C}$, and $975^{\circ} \mathrm{C}$ for $y=0,5,10,15$, and 20 , respectively. In particular, the sintering temperature of 
ceramics decreased to $975^{\circ} \mathrm{C}$ ceramics and the ceramics achieved higher densities at $y=15$. At the same time, the optimum sintering temperature could be reduced with the increase of $\mathrm{H}_{3} \mathrm{BO}_{3}$, thus effectively preventing the volatilization of low melting point $\mathrm{B}_{2} \mathrm{O}_{3}$. In addition, $\mathrm{H}_{3} \mathrm{BO}_{3}$ compensated for the volatilized $\mathrm{B}_{2} \mathrm{O}_{3}$, thus allowing more complete growth of ceramics grains.

Figure 6(a) illustrates the bulk density of $3 \mathrm{MgO}-\mathrm{B}_{2} \mathrm{O}_{3}-2 \mathrm{wt} \% \mathrm{BCB}-y \mathrm{wt} \% \mathrm{H}_{3} \mathrm{BO}_{3}(y=0,5,10,15$, and 20$)$ ceramics as a function of the sintering temperature. Clearly, the bulk density of ceramic first increased and then decreased with the increase of sintering temperature. This phenomenon indicates that the ceramic was effectively sintered denser initially with the sintering temperature increase. Further temperature increase would cause over-sintering of ceramic and resulted in lower density. The bulk density of $3 \mathrm{MgO}-\mathrm{B}_{2} \mathrm{O}_{3}-2 \mathrm{wt} \% \mathrm{BCB}-y \mathrm{wt} \% \mathrm{H}_{3} \mathrm{BO}_{3}(y=0,5,10,15,20)$ ceramics showed an overall increasing trend with the $\mathrm{H}_{3} \mathrm{BO}_{3}$ content increase, which may be attributed to the decrease in porosity, as shown in Fig. 5 . As $y$ increased from 5 to 15 , the bulk density varids from $3.017 \mathrm{~g} / \mathrm{cm}^{3}$ to $3.128 \mathrm{~g} / \mathrm{cm}^{3}$, indicating that the addition of appropriate $\mathrm{H}_{3} \mathrm{BO}_{3}$ could make the ceramic samples sintered more densely. However, with further increasing $x$ value to 20 , the bulk density reached the lowest at $\rho$ of $3.04 \mathrm{~g} / \mathrm{cm}^{3}$, which is due to the over-sintering by addition of too much $\mathrm{H}_{3} \mathrm{BO}_{3}$.

Figure 6(b) demonstrates the change of $\tau_{f}$ for $3 \mathrm{MgO}-\mathrm{B}_{2} \mathrm{O}_{3}-2 \mathrm{wt} \% \mathrm{BCB}-y \mathrm{wt} \% \mathrm{H}_{3} \mathrm{BO}_{3}(0 \leq y \leq 20)$ as a function of temperature. With the sintering temperature increase, $\tau_{f}$ first decreased and then increased, which is consistent with the variation of $Q \times f$ of ceramics. With the increase of $y$, the $\tau_{f}$ first increased and then decreased from $-94.28 \mathrm{ppm} /{ }^{\circ} \mathrm{C}$ to $-53.27 \mathrm{ppm} /{ }^{\circ} \mathrm{C}$. When $y=20$, the $\tau_{f}$ of $3 \mathrm{MgO}-\mathrm{B}_{2} \mathrm{O}_{3}-2 \mathrm{wt} \% \mathrm{BCB}-$ $20 \mathrm{wt} \% \mathrm{H}_{3} \mathrm{BO}_{3}$ ceramics remained stable in the range of -60.2 to $-53.27 \mathrm{ppm} /{ }^{\circ} \mathrm{C}$, which allows the microwave electronic components maintaining temperature stability with a nearly zero temperature coefficient of resonance frequency compared to other ceramics.

Figure 6(c) displays the $\varepsilon_{r}$ of $3 \mathrm{MgO}-\mathrm{B}_{2} \mathrm{O}_{3}-2 \mathrm{wt} \% \mathrm{BCB}-y \mathrm{wt} \% \mathrm{H}_{3} \mathrm{BO}_{3}(y=0,5,10,15$, and 20) as a function of the sintering temperature. The dielectric constants of ceramic materials are generally closely related to bulk density, phase composition, and crystal structure [39, 40]. $\varepsilon_{r}$ first increased to the maximum and then decreased with the increase of temperatures. As shown in Fig. 6 , the change in $\varepsilon_{r}$ with temperature is similar to that of $Q \times f$ and bulk density. However, as the $\mathrm{H}_{3} \mathrm{BO}_{3}$ content increased, the maximum values of dielectric constant for $3 \mathrm{MgO}-\mathrm{B}_{2} \mathrm{O}_{3}-2 \mathrm{wt} \% \mathrm{BCB}-\mathrm{ywt} \% \mathrm{H}_{3} \mathrm{BO}_{3}$ ceramics increased first and then decreased (from 6.95 to 7.05 and then to 6.67 ), which is similar to that of the bulk density of $3 \mathrm{MgO}-\mathrm{B}_{2} \mathrm{O}_{3}-2 \mathrm{wt} \% \mathrm{BCB}$ $y w t \% \mathrm{H}_{3} \mathrm{BO}_{3}$ ceramics with sintering temperature. The dielectric constant increased with the increase of bulk density. As the bulk density of ceramic increased, the number of active particles inside the ceramic was relatively high, and the dielectric constant increased and vice versa.

Figure 6(d) shows the change of $Q \times f 3 M g O-\mathrm{B}_{2} \mathrm{O}_{3}-2 \mathrm{wt} \% \mathrm{BCB}-y \mathrm{wt} \% \mathrm{H}_{3} \mathrm{BO}_{3}(y=0,5,10,15,20)$ ceramics vs the sintering temperature. In general, grain size, porosity, second phase, and microcracks are the main factors to affect the $Q \times f$ of microwave dielectric ceramics [41-43]. In Fig. 6(d), the $Q \times f$ of $3 \mathrm{MgO}-\mathrm{B}_{2} \mathrm{O}_{3}{ }^{-}$ 
$2 w t \% B C B-y w t \% H_{3} \mathrm{BO}_{3}(y=0,5,10,15,20)$ ceramics showed a trend of increasing and then decreasing with the increase of sintering temperature, which is similar to that of the bulk density and relative permittivity. From the analysis of phase structure and microstructure, the microstructure of $3 \mathrm{MgO}-\mathrm{B}_{2} \mathrm{O}_{3}$ $2 \mathrm{wt} \% \mathrm{BCB}-y \mathrm{wt} \% \mathrm{H}_{3} \mathrm{BO}_{3}(y=0,5,10,15,20)$ ceramics is clearly relatively denser, and a second phase is present in addition to the main phase $3 \mathrm{MgO}-\mathrm{B}_{2} \mathrm{O}_{3}$. As $y=15$, the ceramics possessed relatively high $Q \times f$ and maximum density $\rho$ of $3.128 \mathrm{~g} / \mathrm{cm}^{3}$. With increasing the $y$ to 20 , the optimum sintering temperature was $975^{\circ} \mathrm{C}$. Combined with the XRD analysis, it is found that the $Q \times f$ of $3 \mathrm{MgO}-\mathrm{B}_{2} \mathrm{O}_{3}-2 \mathrm{wt} \% \mathrm{BCB}-$ $x w t \% \mathrm{H}_{3} \mathrm{BO}_{3}$ ceramic also reached the maximum value of $113,645 \mathrm{GHz}$ as $x$ increased.The content of the main phase of the ceramic increases as the content of the second phase $\mathrm{MgO}$ in the crystal structure decreases.

Table 1 lists the optimum sintering temperature and microwave dielectric properties of $3 \mathrm{MgO}-\mathrm{B}_{2} \mathrm{O}_{3}$ $x w t \% B C B-y w t \% \mathrm{H}_{3} \mathrm{BO}_{3}$ (where $x=2,4,6$, and $8 ; y=0,5,10,15$, and 20) ceramics. The optimum sintering temperature decreased with the increase of $\mathrm{BCB}$ content when the value of $y$ was constant. Notably, the sintering temperature of $3 \mathrm{MgO}-\mathrm{B}_{2} \mathrm{O}_{3}-8 \mathrm{wt} \% \mathrm{BCB}$ and $3 \mathrm{MgO}-\mathrm{B}_{2} \mathrm{O}_{3}-8 \mathrm{wt} \% \mathrm{BCB}-5 \mathrm{wt} \% \mathrm{H}_{3} \mathrm{BO}_{3}$ ceramics can be lowered to $925^{\circ} \mathrm{C}\left(<961^{\circ} \mathrm{C}\right.$, providing the possibility of cofiring with $\left.\mathrm{Ag}\right)$. Both ceramics had high quality factors and low dielectric constants. The microwave dielectric properties of $3 \mathrm{MgO}-\mathrm{B}_{2} \mathrm{O}_{3}-8 \mathrm{wt} \% \mathrm{BCB}$ are as follows: $\varepsilon_{r}=6.47, Q \times f=73,233 \mathrm{GHz}, \tau_{f}=-68.52 \mathrm{ppm} /{ }^{\circ} \mathrm{C}$. The microwave properties of $3 \mathrm{MgO}-\mathrm{B}_{2} \mathrm{O}_{3}{ }^{-}$ $8 \mathrm{wt} \% \mathrm{BCB}-5 \mathrm{wt} \% \mathrm{H}_{3} \mathrm{BO}_{3}$ are as follows: $\varepsilon_{r}=6.64, Q \times f=78,173 \mathrm{GHz}$, and $\tau_{f}=-57.27 \mathrm{ppm} /{ }^{\circ} \mathrm{C}$. In addition, the $3 \mathrm{MgO}-\mathrm{B}_{2} \mathrm{O}_{3}-2 \mathrm{wt} \% \mathrm{BCB}-20 \mathrm{wt} \% \mathrm{H}_{3} \mathrm{BO}_{3}$ ceramic has the highest quality factor of $113,645 \mathrm{GHz}$ at $975^{\circ} \mathrm{C}$, a $\varepsilon_{r}$ of 6.67 , and a $\tau_{f}$ of $-53.19 \mathrm{ppm} /{ }^{\circ} \mathrm{C}$. As observed by $\mathrm{XRD}$, the increase in $\mathrm{H}_{3} \mathrm{BO}_{3}$ content not only decreased the sintering temperature but also enhanced the intensity of the diffraction peak for $\mathrm{Mg}_{3} \mathrm{~B}_{2} \mathrm{O}_{6}$, which indicates that $Q \times f$ increased with the increase of $\mathrm{Mg}_{3} \mathrm{~B}_{2} \mathrm{O}_{6}$ content. However, when $y=20$, the $Q \times f$ decreased with the increase of $\mathrm{BCB}$, indicating that although $\mathrm{BCB}$ plays the role as sintering aid, it also deteriorates the microwave dielectric properties of $3 \mathrm{MgO}-\mathrm{B}_{2} \mathrm{O}_{3}-x \mathrm{wt} \% \mathrm{BCB}-20 \mathrm{wt} \% \mathrm{H}_{3} \mathrm{BO}_{3}$. 
Table 1

Optimum sintering temperature and microwave dielectric properties of $3 \mathrm{MgO}-\mathrm{B}_{2} \mathrm{O}_{3}$ $x w t \% B C B-y w t \% \mathrm{H}_{3} \mathrm{BO}_{3}$ ceramics

\begin{tabular}{|c|c|c|c|c|}
\hline Compound & S.T. $\left({ }^{\circ} \mathrm{C}\right)$ & $Q \times f(G H z)$ & $\varepsilon_{r}$ & $\tau_{f}\left(\mathrm{ppm} /{ }^{\circ} \mathrm{C}\right)$ \\
\hline $3 \mathrm{MgO}-\mathrm{B}_{2} \mathrm{O}_{3}-2 \mathrm{wt} \% \mathrm{BCB}$ & $1050^{\circ} \mathrm{C}$ & 73,674 & 6.95 & -68.38 \\
\hline $3 \mathrm{MgO}-\mathrm{B}_{2} \mathrm{O}_{3}-4 \mathrm{wt} \% \mathrm{BCB}$ & $1025^{\circ} \mathrm{C}$ & 99,008 & 7.36 & -59.38 \\
\hline $3 \mathrm{MgO}-\mathrm{B}_{2} \mathrm{O}_{3}-6 \mathrm{wt} \% \mathrm{BCB}$ & $975^{\circ} \mathrm{C}$ & 69,263 & 6.78 & -73.01 \\
\hline $3 \mathrm{MgO}-\mathrm{B}_{2} \mathrm{O}_{3}-8 \mathrm{wt} \% \mathrm{BCB}$ & $950^{\circ} \mathrm{C}$ & 75,222 & 6.64 & -64.92 \\
\hline $3 \mathrm{MgO}-\mathrm{B}_{2} \mathrm{O}_{3}-2 \mathrm{wt} \% \mathrm{BCB}-5 \mathrm{wt} \% \mathrm{H}_{3} \mathrm{BO}_{3}$ & $1000^{\circ} \mathrm{C}$ & 89,283 & 7.05 & -61.53 \\
\hline $3 \mathrm{MgO}-\mathrm{B}_{2} \mathrm{O}_{3}-4 \mathrm{wt} \% \mathrm{BCB}-5 \mathrm{wt} \% \mathrm{H}_{3} \mathrm{BO}_{3}$ & $975^{\circ} \mathrm{C}$ & 69,055 & 6.92 & -86.84 \\
\hline $3 \mathrm{MgO}-\mathrm{B}_{2} \mathrm{O}_{3}-6 \mathrm{wt} \% \mathrm{BCB}-5 \mathrm{wt} \% \mathrm{H}_{3} \mathrm{BO}_{3}$ & $975^{\circ} \mathrm{C}$ & 80,260 & 6.65 & -57.93 \\
\hline $3 \mathrm{MgO}-\mathrm{B}_{2} \mathrm{O}_{3}-8 \mathrm{wt} \% \mathrm{BCB}-5 \mathrm{wt} \% \mathrm{H}_{3} \mathrm{BO}_{3}$ & $925^{\circ} \mathrm{C}$ & 78,173 & 6.64 & -57.27 \\
\hline $3 \mathrm{MgO}-\mathrm{B}_{2} \mathrm{O}_{3}-2 \mathrm{wt} \% \mathrm{BCB}-10 \mathrm{wt} \% \mathrm{H}_{3} \mathrm{BO}_{3}$ & $1025^{\circ} \mathrm{C}$ & 77,819 & 7.04 & -94.28 \\
\hline $3 \mathrm{MgO}-\mathrm{B}_{2} \mathrm{O}_{3}-4 \mathrm{wt} \% \mathrm{BCB}-10 \mathrm{wt} \% \mathrm{H}_{3} \mathrm{BO}_{3}$ & $1000^{\circ} \mathrm{C}$ & 72,409 & 6.93 & -65.74 \\
\hline $3 \mathrm{MgO}-\mathrm{B}_{2} \mathrm{O}_{3}-6 \mathrm{wt} \% \mathrm{BCB}-10 \mathrm{wt} \% \mathrm{H}_{3} \mathrm{BO}_{3}$ & $950^{\circ} \mathrm{C}$ & 69,740 & 6.8 & -86.99 \\
\hline $3 \mathrm{MgO}-\mathrm{B}_{2} \mathrm{O}_{3}-8 \mathrm{wt} \% \mathrm{BCB}-10 \mathrm{wt} \% \mathrm{H}_{3} \mathrm{BO}_{3}$ & $950^{\circ} \mathrm{C}$ & 58,689 & 6.95 & -62.86 \\
\hline $3 \mathrm{MgO}-\mathrm{B}_{2} \mathrm{O}_{3}-2 \mathrm{wt} \% \mathrm{BCB}-15 \mathrm{wt} \% \mathrm{H}_{3} \mathrm{BO}_{3}$ & $975^{\circ} \mathrm{C}$ & 73,892 & 9.79 & -66.80 \\
\hline $3 \mathrm{MgO}-\mathrm{B}_{2} \mathrm{O}_{3}-4 \mathrm{wt} \% \mathrm{BCB}-15 \mathrm{wt} \% \mathrm{H}_{3} \mathrm{BO}_{3}$ & $975^{\circ} \mathrm{C}$ & 74,136 & 6.95 & -27.46 \\
\hline $3 \mathrm{MgO}-\mathrm{B}_{2} \mathrm{O}_{3}-6 \mathrm{wt} \% \mathrm{BCB}-15 \mathrm{wt} \% \mathrm{H}_{3} \mathrm{BO}_{3}$ & $950^{\circ} \mathrm{C}$ & 83,205 & 6.72 & -65.05 \\
\hline $3 \mathrm{MgO}-\mathrm{B}_{2} \mathrm{O}_{3}-8 \mathrm{wt} \% \mathrm{BCB}-15 \mathrm{wt} \% \mathrm{H}_{3} \mathrm{BO}_{3}$ & $900^{\circ} \mathrm{C}$ & 63,711 & 6.51 & -60.79 \\
\hline $3 \mathrm{MgO}-\mathrm{B}_{2} \mathrm{O}_{3}-2 \mathrm{wt} \% \mathrm{BCB}-20 \mathrm{wt} \% \mathrm{H}_{3} \mathrm{BO}_{3}$ & $975^{\circ} \mathrm{C}$ & 113,645 & 6.67 & -53.19 \\
\hline $3 \mathrm{MgO}-\mathrm{B}_{2} \mathrm{O}_{3}-4 \mathrm{wt} \% \mathrm{BCB}-20 \mathrm{wt} \% \mathrm{H}_{3} \mathrm{BO}_{3}$ & $975^{\circ} \mathrm{C}$ & 81,667 & 6.55 & -50.21 \\
\hline $3 \mathrm{MgO}-\mathrm{B}_{2} \mathrm{O}_{3}-6 \mathrm{wt} \% \mathrm{BCB}-20 \mathrm{wt} \% \mathrm{H}_{3} \mathrm{BO}_{3}$ & $950^{\circ} \mathrm{C}$ & 74,099 & 6.51 & -66.98 \\
\hline $3 \mathrm{MgO}-\mathrm{B}_{2} \mathrm{O}_{3}-8 \mathrm{wt} \% \mathrm{BCB}-20 \mathrm{wt} \% \mathrm{H}_{3} \mathrm{BO}_{3}$ & $950^{\circ} \mathrm{C}$ & 78,401 & 6.53 & -62.85 \\
\hline
\end{tabular}

To investigate whether the $3 \mathrm{MgO}-\mathrm{B}_{2} \mathrm{O}_{3}-6 \mathrm{wt} \% \mathrm{BCB}-15 \mathrm{wt} \%_{3} \mathrm{HO}_{3}$ and $3 \mathrm{MgO}-\mathrm{B}_{2} \mathrm{O}_{3}-8 \mathrm{wt} \% \mathrm{BCB}-5 \mathrm{wt} \% \mathrm{H}_{3} \mathrm{BO}_{3}$ ceramics could reacedt with silver electrodes or not, the two calcined powders were mixed with $20 \mathrm{wt} \% \mathrm{Ag}$ powder and sintered at $950^{\circ} \mathrm{C}$ and $925^{\circ} \mathrm{C}$ for 4 hours, respectively. Figure 7 shows the XRD patterns and backscattered electron diagrams of the samples. The XRD shows that Ag was present as a single phase 
and the EDS shows that the bright particles in the main ceramic matrix were silver, which further confirms that there is no reaction between the silver and $3 \mathrm{MgO}-\mathrm{B}_{2} \mathrm{O}_{3}-8 \mathrm{wt} \% \mathrm{BCB}-5 \mathrm{wt} \% \mathrm{H}_{3} \mathrm{BO}_{3}$. All these results evidence the potential application of both ceramics in LTCC technology.

\section{Conclusion}

In this study, $3 \mathrm{MgO}-\mathrm{B}_{2} \mathrm{O}_{3}-x \mathrm{wt} \% \mathrm{BCB}-y \mathrm{wt} \% \mathrm{H}_{3} \mathrm{BO}_{3}$ (where $x=2,4,6$, and $8 ; \mathrm{y}=0,5,10,15$, and 20) ceramics was synthesized using solid-phase reaction method. When $y=0$, the ceramics consist of two phases, namely $\mathrm{Mg}_{3} \mathrm{~B}_{2} \mathrm{O}_{6}$ and $\mathrm{MgO}$. As $x$ increased, the main diffraction peak of $\mathrm{MgO}$ phase gradually decreased while the diffraction peak of $\mathrm{Mg}_{3} \mathrm{~B}_{2} \mathrm{O}_{6}$ gradually increased. As $x$ was constant, the diffraction peak intensity of $\mathrm{Mg}_{3} \mathrm{~B}_{2} \mathrm{O}_{6}$ phase increased with the increase of $y$ while the main diffraction peak of $\mathrm{MgO}$ phase continuously decreased. $\mathrm{H}_{3} \mathrm{BO}_{3}$ could effectively stabilize the $\mathrm{Mg}_{3} \mathrm{~B}_{2} \mathrm{O}_{6}$ phase. $\mathrm{BCB}$ acted as a grain refinement and reduced the optimum sintering temperature of ceramics from $1,050^{\circ} \mathrm{C}$ to $950^{\circ} \mathrm{C}$. When $x=4$ and $y=0,3 \mathrm{MgO}-\mathrm{B}_{2} \mathrm{O}_{3}-4 \mathrm{wt} \% \mathrm{BCB}$ exhibited excellent microwave dielectric properties: $\varepsilon_{r}=7.36$, $Q \times f=99,008 \mathrm{GHz}, \tau_{f}=-59.38 \mathrm{ppm} /{ }^{\circ} \mathrm{C}$, and $\rho=2.791 \mathrm{~g} / \mathrm{cm}$. However, excess BCB led to a decrease of microwave dielectric properties. It was found that an appropriate amount of $\mathrm{H}_{3} \mathrm{BO}_{3}$ compensated the boron content of $3 \mathrm{MgO}-\mathrm{B}_{2} \mathrm{O}_{3}$, making $3 \mathrm{MgO}-\mathrm{B}_{2} \mathrm{O}_{3}$ crystal growth more complete and denser. The highest Qxf of $113,645 \mathrm{GHz}, \varepsilon_{r}$ of $6.67, \tau_{f}$ of $-53.19 \mathrm{ppm} /{ }^{\circ} \mathrm{C}$, and $\rho$ of $3.04 \mathrm{~g} / \mathrm{cm}^{3}$ of $3 \mathrm{MgO}-\mathrm{B}_{2} \mathrm{O}_{3}$ ceramic were achieved at $975^{\circ} \mathrm{C}$ at $x=2$ and $y=20$. In particular, comprehensive comparison of the ceramic properties sintered at same low sintering temperature revealed that the ceramics with $x=6, y=15$ sintered at $950^{\circ} \mathrm{C}$ achieved good microwave dielectric properties with a $\varepsilon_{r}$ of $6.72, Q \times f$ of $83,205 \mathrm{GHz}$, and $\tau_{f}$ of -65.05 $\mathrm{ppm} /{ }^{\circ} \mathrm{C}$. The ceramic with $x=8, y=5$ sintered at $925^{\circ} \mathrm{C}$ also achieved good microwave dielectric properties $\left(\varepsilon_{r}=6.64, Q x f=78173 \mathrm{GHz}\right.$, and $\left.\tau_{f}=-57.27 \mathrm{ppm} /{ }^{\circ} \mathrm{C}\right) .3 \mathrm{MgO}-\mathrm{B}_{2} \mathrm{O}_{3}-x$ wt\%BCB- $y$ wt $\%_{\mathrm{H}_{3}} \mathrm{BO}_{3}(x=$ $6, y=15$ or $x=8, y=5$ ) had excellent microwave dielectric properties and can also be produced at low cost. Both ceramics can be co-fired with Ag, suggesting that they are promising for $5 \mathrm{G}$ applications, provided that $\tau_{f}$ can be further optimized to zero.

\section{Declarations}

\section{Acknowledgements}

This work was supported by Natural Science Foundation of China (Nos. 61761015 and12064007), Natural Science Foundation of Guangxi (Nos. 2018GXNSFFA050001, 2017GXNSFDA198027 and 2017GXNSFFA198011), High Level Innovation

\section{References}

1. Guo HH, Zhou D, Du C et al (2020) Temperature stable $\mathrm{Li}_{2} \mathrm{Ti}_{0.75}\left(\mathrm{Mg}_{1 / 3} \mathrm{Nb}_{2 / 3}\right)_{0.25} \mathrm{O}_{3}$ based microwave dielectric ceramics with low sintering temperature and ultra-low dielectric loss for dielectric resonator 
antenna applications. Journal of Materials Chemistry C 8:4690-4700

2. Chu YJ, Jean JH (2013) Low-fire processing of microwave $\mathrm{BaTi}_{4} \mathrm{O}_{9}$ dielectric with crystalline $\mathrm{CuB}_{2} \mathrm{O}_{4}$ and $\mathrm{BaCuB}_{2} \mathrm{O}_{5}$ additives. Ceram Int 39:5151-5158

3. Arun S, Sebastian MT, Surendran KP (2017) $\mathrm{Li}_{2} \mathrm{ZnTi}_{3} \mathrm{O}_{8}$ based High k LTCC tapes for improved thermal management in hybrid circuit applications. Ceram Int 43:5509-5516

4. Zhu HY, Fu RL, Agathopoulos S et al (2018) Crystallization behaviour and properties of BaO-CaO$\mathrm{B}_{2} \mathrm{O}_{3}-\mathrm{SiO}_{2}$ glasses and glass-ceramics for LTCC applications. Ceram Int 44:10147-10153

5. Qin TY, Zhong CW, Tang B et al (2021) A novel type of composite LTCC material for high flexural strength application. J Eur Ceram Soc 41:1342-1351

6. Kato J, Fujii M, Kagata $\mathrm{H}$ et al (1993) Crystal structure refinement of $\left(\mathrm{Pb}_{1-x} \mathrm{Ca}_{x}\right) \mathrm{ZrO}_{3}$ by the rietvelt method. Jpn J Appl Phys Part 1-Regular Papers Short Notes Review Papers 32:4356-4359

7. Yang HY, Zhang SR, Chen YW et al (2019) Low-firing, temperature stable and improved microwave dielectric properties of $\mathrm{ZnO}-\mathrm{TiO}_{2}-\mathrm{Nb}_{2} \mathrm{O}_{5}$ composite ceramics. Journal of Materiomics 5:471-479

8. Lin QB, Song KX, Liu B et al (2020) Vibrational spectroscopy and microwave dielectric properties of $\mathrm{AY}_{2} \mathrm{Si}_{3} \mathrm{O}_{10}(\mathrm{~A}=\mathrm{Sr}, \mathrm{Ba})$ ceramics for $5 \mathrm{G}$ applications. Ceram Int 46:1171-1177

9. Fan J, Du K, Zou ZY et al (2021) Impedance spectroscopy, B-site cation ordering and structureproperty relations of $(1-x)\left[\mathrm{LaAl}_{0.9}\left(\mathrm{Mg}_{0.5} \mathrm{Ti}_{0.5}\right)\right]_{0.1} \mathrm{O}_{3}-x \mathrm{CaTiO}{ }_{3}$ ceramics for $5 \mathrm{G}$ dielectric waveguide filters. Ceram Int 47:15319-15327

10. Wang DW, Chen JR, Wang G et al (2020) Cold sintered $\mathrm{LiMgPO}_{4}$ based composites for low temperature co-fired ceramic (LTCC) applications. J Am Ceram Soc 103:6237-6244

11. Yang HC, Zhang SR, Wen QY et al (2021) Synthesis of $\mathrm{CaAl}_{2} \mathrm{~B}_{2} \mathrm{O}_{4}+3 x$ : Novel microwave dielectric ceramics with low permittivity and low loss. J Eur Ceram Soc 41:2596-2601

12. Guo HH, Fu MS, Zhou D et al (2021) Design of a High-efficiency and-gain antenna using novel lowloss, temperature-stable $\mathrm{Li}_{2} \mathrm{Ti}_{1-x}\left(\mathrm{Cu}_{1 / 3} \mathrm{Nb}_{2 / 3}\right)_{x} \mathrm{O}_{3}$ Microwave Dielectric Ceramics. ACS Appl Mater Interfaces 13:912-923

13. Ni LZ, Li LX, Du MK et al (2021) Wide temperature stable $\mathrm{Ba}\left(\mathrm{Mg}_{x} \mathrm{Ta}_{2 / 3}\right) \mathrm{O}_{3}$ microwave dielectric ceramics with ultra-high-Q applied for $5 \mathrm{G}$ dielectric filter. Ceram Int 47:1034-1039

14. Wang KG, Zhou HF, Liu XB et al (2019) A lithium aluminium borate composite microwave dielectric ceramic with low permittivity, near-zero shrinkage, and low sintering temperature. J Eur Ceram Soc 39:1122-1126

15. Zhou HF, Tan XH, Huang J et al (2017) Sintering behavior, phase structure and adjustable microwave dielectric properties of $\mathrm{Li}_{2} \mathrm{O}-\mathrm{MgO}-n \mathrm{TiO}_{2}$ ceramics $(1 \leq n \leq 5)$. J Mater Sci: Mater Electron 28:64756480

16. Sebastian MT, Jantunen H (2008) Low loss dielectric materials for LTCC applications: a review. Int Mater Rev 53:57-90 
17. Yang HC, Zhang SR, Yang HY et al (2020) $\mathrm{Gd}_{2} \mathrm{Zr}_{3}\left(\mathrm{MoO}_{4}\right)_{9}$ microwave dielectric ceramics with trigonal structure for LTCC application. J Am Ceram Soc 103:1131-1139

18. Zhou HF, Tan XH, Liu XB et al (2018) Low permittivity MgO- $x \mathrm{~B}_{2} \mathrm{O}_{3}-y \mathrm{BaCu}\left(\mathrm{B}_{2} \mathrm{O}_{5}\right)$ microwave dielectric ceramics for low temperature co-fired ceramics technology. J Mater Sci: Mater Electron 29:1848618492

19. Fan GC, Zhou HF, Chen XL (2017) Optimized sintering temperature and enhanced microwave dielectric performance of $\mathrm{Mg}_{2} \mathrm{~B}_{2} \mathrm{O}_{5}$ ceramic. J Mater Sci: Mater Electron 28:818-822

20. Wang G, Jiang J, Dou ZM et al (2016) Sintering behavior and microwave dielectric properties of $0.67 \mathrm{CaTiO}_{3}-0.33 \mathrm{LaAlO}_{3}$ ceramics modified by $\mathrm{B}_{2} \mathrm{O}_{3}-\mathrm{Li}_{2} \mathrm{O}-\mathrm{Al}_{2} \mathrm{O}_{3}$ and $\mathrm{CeO}_{2}$. Ceram Int 42:1100311009

21. Dosler U, Krzmanc MM, Suvorov D (2010) The synthesis and microwave dielectric properties of $\mathrm{Mg}_{3} \mathrm{~B}_{2} \mathrm{O}_{6}$ and $\mathrm{Mg}_{2} \mathrm{~B}_{2} \mathrm{O}_{5}$ ceramics. J Eur Ceram Soc 30:413-418

22. Gu YJ, Ding XB, Hu W et al (2020) Effect of $\mathrm{Mg} / \mathrm{B}$ ratio and $\mathrm{Sr}^{2+}$ substitution for $\mathrm{Mg}^{2+}$ on the sintering, phase composition and microwave dielectric properties of $\mathrm{Mg}_{3} \mathrm{~B}_{2} \mathrm{O}_{6}$ ceramics. Ceram Int 46:25888-25894

23. Kan A, Ogawa $\mathrm{H}$, Sumino $\mathrm{M}$ et al (2009) Microwave dielectric properties of $x \mathrm{MgO}-(1-x) \mathrm{B}_{2} \mathrm{O}_{3}$ ceramics. Jpn J Appl Phys 48:5

24. Gu YJ, Yang XH, Ding XB et al (2020) A low-cost $\left(\mathrm{Mg}_{1-\mathrm{x}} \mathrm{Ca}_{\mathrm{x}}\right)_{3} \mathrm{~B}_{2} \mathrm{O}_{6}(0 \leq \mathrm{x} \leq 1.0$ mol.\%) ceramic with enhanced microwave dielectric properties. J Mater Sci: Mater Electron 31:18289-18296

25. Peng R, Su H, Li YX et al. Microstructure and microwave dielectric properties of Ni doped zinc borate ceramics for LTCC applications. J Alloys Compd 2021, 868

26. Peng R, Li YX, Su H et al. Three-phase borate solid solution with low sintering temperature, highquality factor, and low dielectric constant. J Am Ceram Soc 2021

27. Dou G, Guo M, Li YX et al (2015) The effect of LMBS glass on the microwave dielectric properties of the $\mathrm{Mg}_{3} \mathrm{~B}_{2} \mathrm{O}_{6}$ for LTCC. J Mater Sci: Mater Electron 26:4207-4211

28. Zhou DX, Sun F, Hu YX et al (2012) Low-temperature sintering and microwave dielectric properties of $\mathrm{Mg}_{3} \mathrm{~B}_{2} \mathrm{O}_{6}$-LMZBS composites. J Mater Sci: Mater Electron 23:981-989

29. Guo J, Zhou D, Wang $\mathrm{H}$ et al (2012) Microwave and infrared dielectric response of temperature stable $(1-x) \mathrm{BaMoO}_{4}-x \mathrm{TiO}_{2}$ composite ceramics. J Am Ceram Soc 95:232-237

30. Zhang YH, Liu QQ, Wu HT (2018) Low-temperature sintering and microwave dielectric properties of $\mathrm{H}_{3} \mathrm{BO}_{3}$-doped $\mathrm{Li}_{2} \mathrm{Mg}_{3} \mathrm{Ti}_{0.95}\left(\mathrm{Mg}_{1 / 3} \mathrm{Nb}_{2 / 3}\right)_{0.05} \mathrm{O}_{6}$ ceramics. Ceram Int 44:17526-17529

31. Kumar TS, Pamu D (2015) Effect of $\mathrm{V}_{2} \mathrm{O}_{5}$ on microwave dielectric properties of non-stoichiometric $\mathrm{MgTiO}_{3}$ ceramics. Mater Sci Eng: B-Advanced Functional Solid-State Materials 194:86-93

32. Zhou HF, Wang H, Li KC et al (2009) Effect of $\mathrm{B}_{2} \mathrm{O}_{3}$ and $\mathrm{CuO}$ additions on the sintering temperature and microwave dielectric properties of $3 \mathrm{Li}_{2} \mathrm{O}-\mathrm{Nb}_{2} \mathrm{O}_{5}-3 \mathrm{TiO}_{2}$ ceramics. J Mater Sci: Mater Electron 20:283-288 
33. Kim MH, Jeong $\mathrm{YH}, \mathrm{Nahm} S$ et al (2006) Effect of $\mathrm{B}_{2} \mathrm{O}_{3}$ and $\mathrm{CuO}$ additives on the sintering temperature and microwave dielectric properties of $\mathrm{Ba}\left(\mathrm{Zn}_{1 / 3} \mathrm{Nb}_{2 / 3}\right) \mathrm{O}_{3}$ ceramics. J Eur Ceram Soc 26:2139-2142

34. Silva MAS, Oliveira RGM, Sombra ASB (2019) Dielectric and microwave properties of common sintering aids for the manufacture of thermally stable ceramics. Ceram Int 45:20446-20450

35. Kim MH, Lim JB, Kim JC et al (2006) Synthesis of $\mathrm{BaCu}\left(\mathrm{B}_{2} \mathrm{O}_{5}\right)$ ceramics and their effect on the sintering temperature and microwave dielectric properties of $\mathrm{Ba}\left(\mathrm{Zn}_{1 / 3} \mathrm{Nb}_{2 / 3}\right) \mathrm{O}_{3}$ ceramics. $\mathrm{J} \mathrm{Am}$ Ceram Soc 89:3124-3128

36. Tang B, Guo X, Yu SQ et al (2015) The shrinking process and microwave dielectric properties of $\mathrm{BaCu}\left(\mathrm{B}_{2} \mathrm{O}_{5}\right)$-added 0.85BaTi $\mathrm{O}_{9}-0.15 \mathrm{BaZn}_{2} \mathrm{Ti}_{4} \mathrm{O}_{11}$ ceramics. Mater Res Bull 66:163-168

37. Chen XL, Zhou HF, Fang $L$ et al (2011) Microwave dielectric properties and its compatibility with silver electrode of $\mathrm{LiNb}_{0.6} \mathrm{Ti}_{0.5} \mathrm{O}_{3}$ with $\mathrm{B}_{2} \mathrm{O}_{3}$ and $\mathrm{CuO}$ additions. J Mater Sci: Mater Electron 22:371375

38. Zhou HF, Tan XH, Huang J et al (2017) Phase structure, sintering behavior and adjustable microwave dielectric properties of $\mathrm{Mg}_{1-x} \mathrm{Li}_{2 x} \mathrm{Ti}_{x} \mathrm{O}_{1+2 x}$ solid solution ceramics. J Alloys Compd 696:1255-1259

39. Zhang P, Zhao YG, Li LX (2015) The correlations among bond ionicity, lattice energy and microwave dielectric properties of $\left(\mathrm{Nd}_{1-x} \mathrm{La}_{x}\right) \mathrm{NbO}_{4}$ ceramics. PCCP 17:16692-16698

40. Zhao YG, Zhang $P$ (2016) High-Q microwave dielectric ceramics using $\mathrm{Zn}_{3} \mathrm{Nb}_{1.88} \mathrm{Ta}_{0.12} \mathrm{O}_{8}$ solid solutions. J Alloys Compd 662:455-460

41. Lan XK, Li J, Zou ZY et al (2019) Lattice structure analysis and optimised microwave dielectric properties of $\mathrm{LiAl}_{1-x}\left(\mathrm{Zn}_{0.5} \mathrm{Si}_{0.5}\right)_{x} \mathrm{O}_{2}$ solid solutions. J Eur Ceram Soc 39:2360-2364

42. Ferreira VM, Baptista JL (1994) Preparation and microwave dielectric properties of pure and doped magnesium titanate ceramics. Mater Res Bull 29:1017-1023

43. Lei W, Lu WZ, Wang XC et al (2009) Effects of $\mathrm{CaTiO}_{3}$ on Microstructures and Properties of (1$x) \mathrm{ZnAl}_{2} \mathrm{O}_{4}-x \mathrm{Mg}_{2} \mathrm{TiO}_{4}(x=0.1)$ Microwave Dielectric Ceramics. Journal of Inorganic Materials 24:957961

\section{Figures}




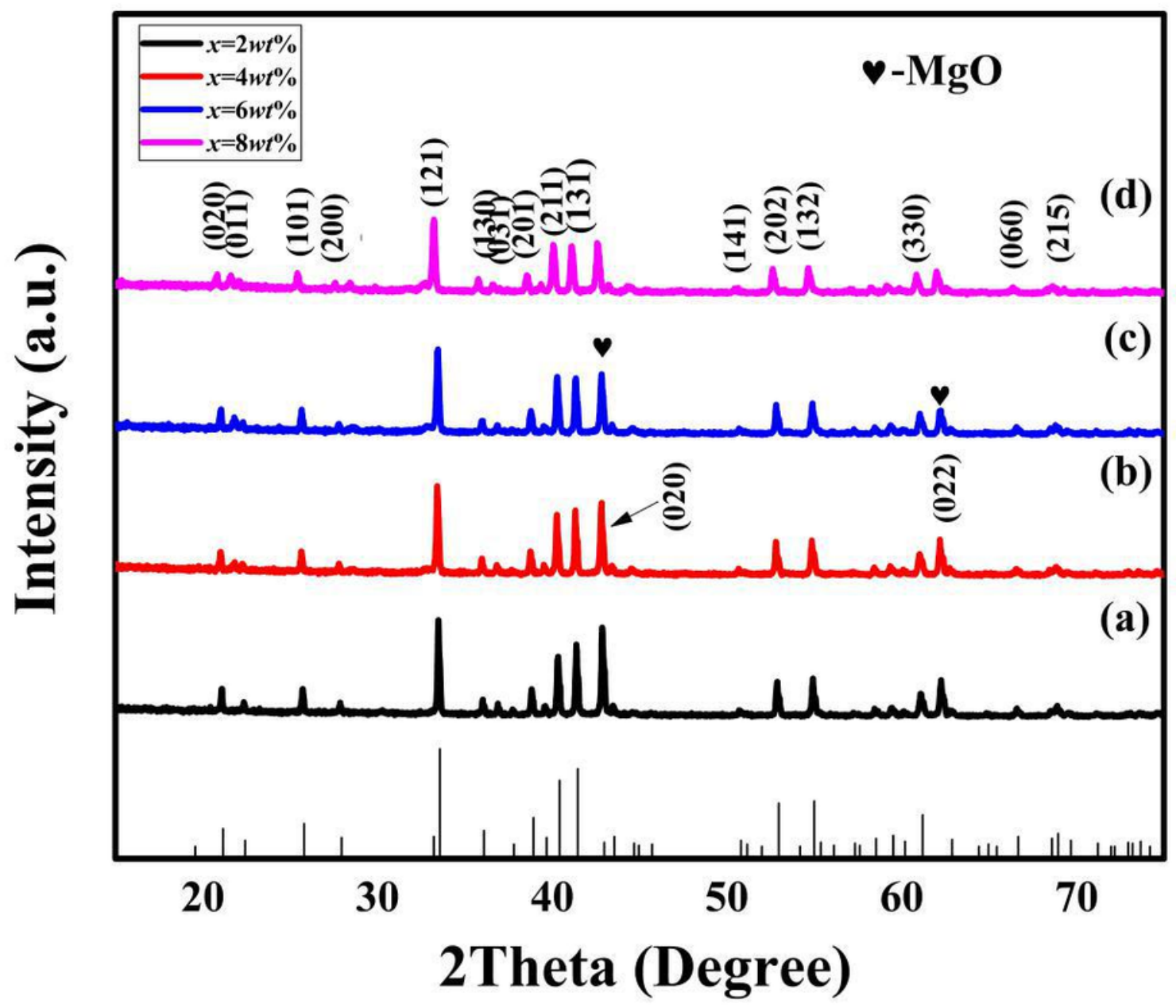

Figure 1

XRD patterns of 3MgO-B203-xwt $\% B C B(x=2,4,6,8)$ ceramics sintered at optimum temperatures: $(a) x=$ $2,1050{ }^{\circ} \mathrm{C}$, (b) $\mathrm{x}=4,1025^{\circ} \mathrm{C}$, (c) $\mathrm{x}=6,975^{\circ} \mathrm{C}$, (d) $\mathrm{x}=8,950^{\circ} \mathrm{C}$. 

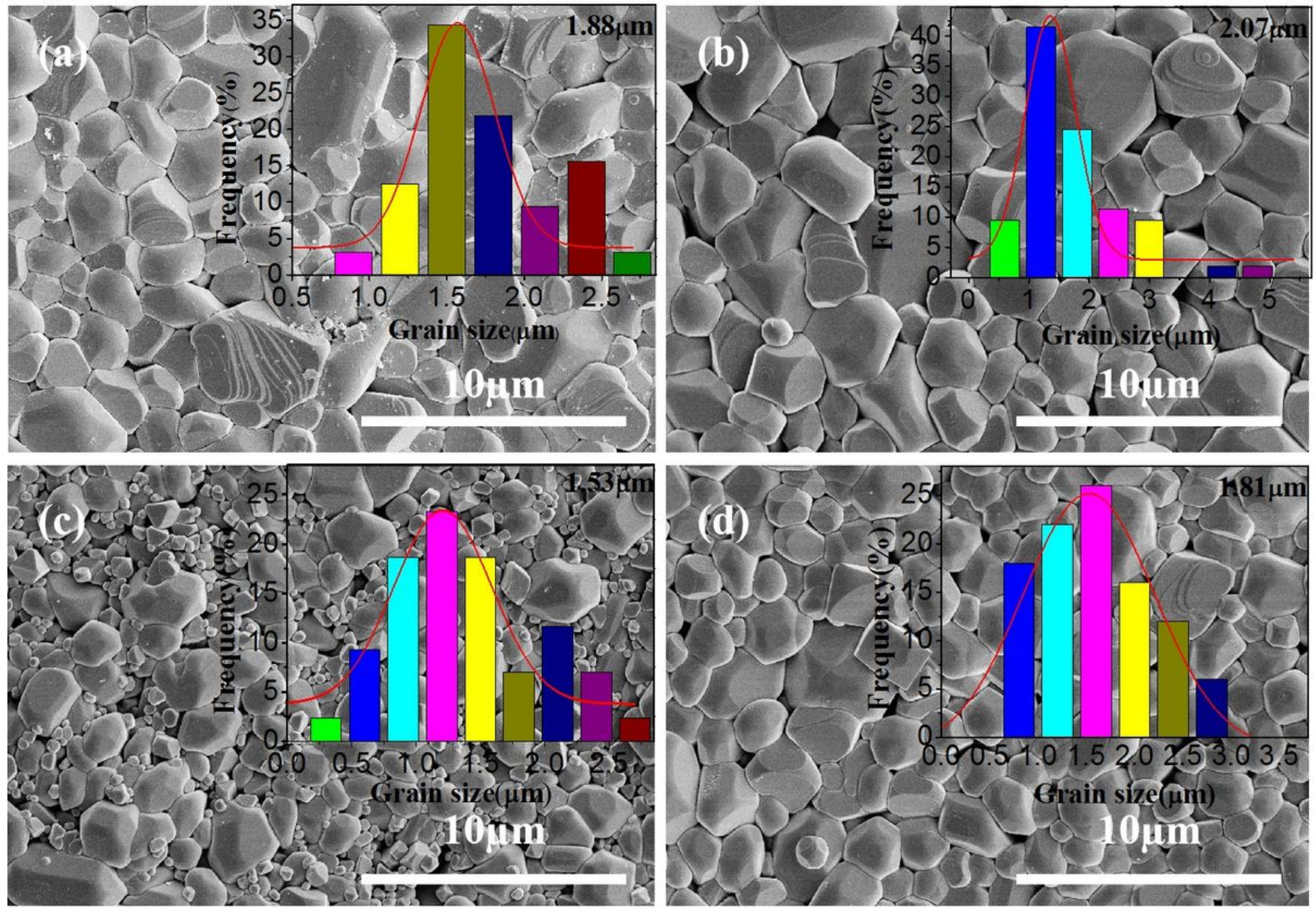

Figure 2

SEM image of 3Mg0-B2O3-xwt\%BCB $(x=2,4,6,8)$ ceramics sintered at optimum temperatures: (a) $x=2$, $1050^{\circ} \mathrm{C}$, (b) $\mathrm{x}=4,1025^{\circ} \mathrm{C}$, (c) $\mathrm{x}=6,975^{\circ} \mathrm{C}$, (d) $\mathrm{x}=8,950^{\circ} \mathrm{C}$. 


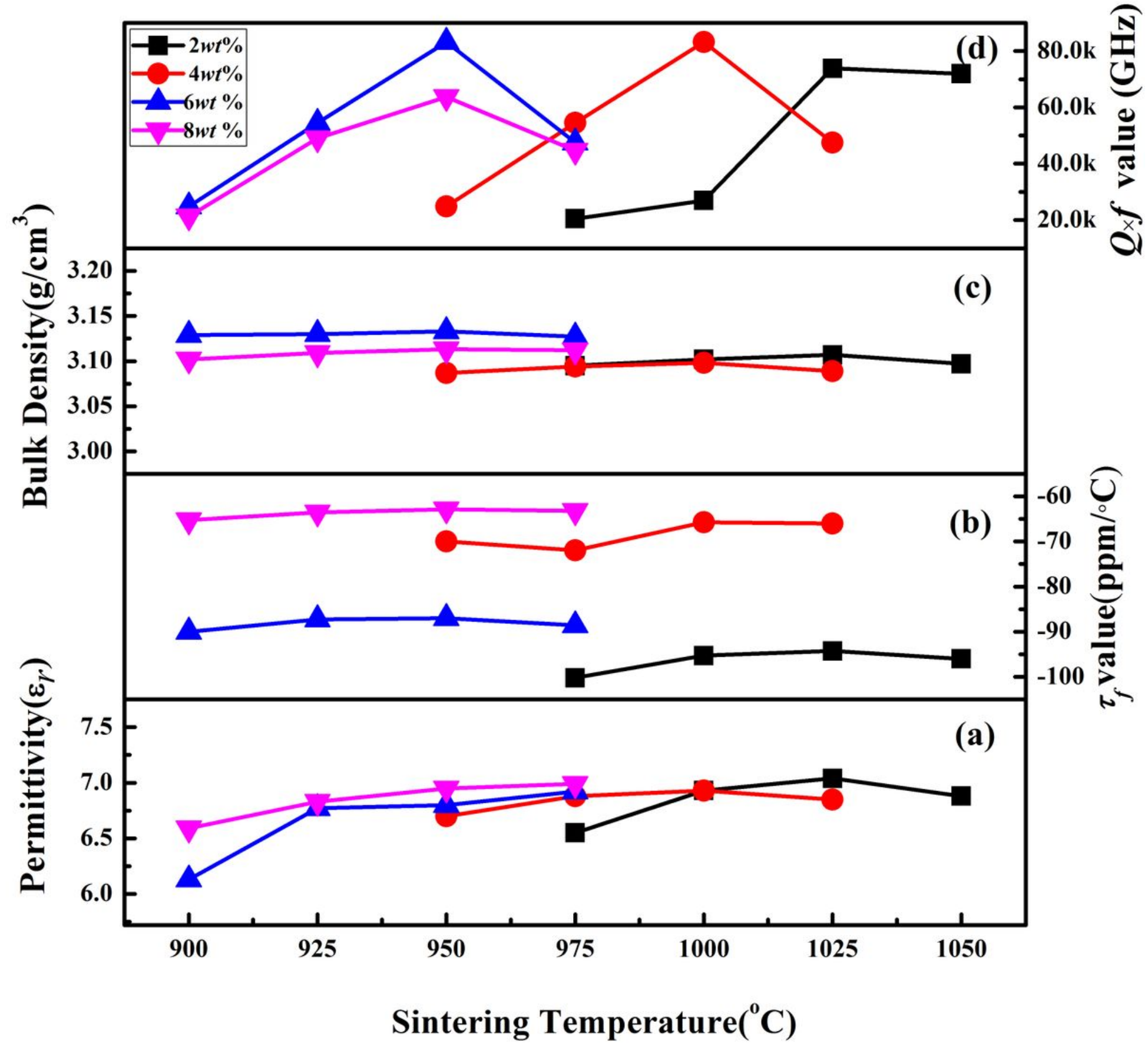

Figure 3

Bulk densities and microwave dielectric properties ( $\varepsilon r$, Qxf and $\tau f$ ) of the 3MgO-B203-xwt\%BCB ( $x$ value ranges from 2 to 8 ) ceramics at different sintering temperatures (S.T.) 


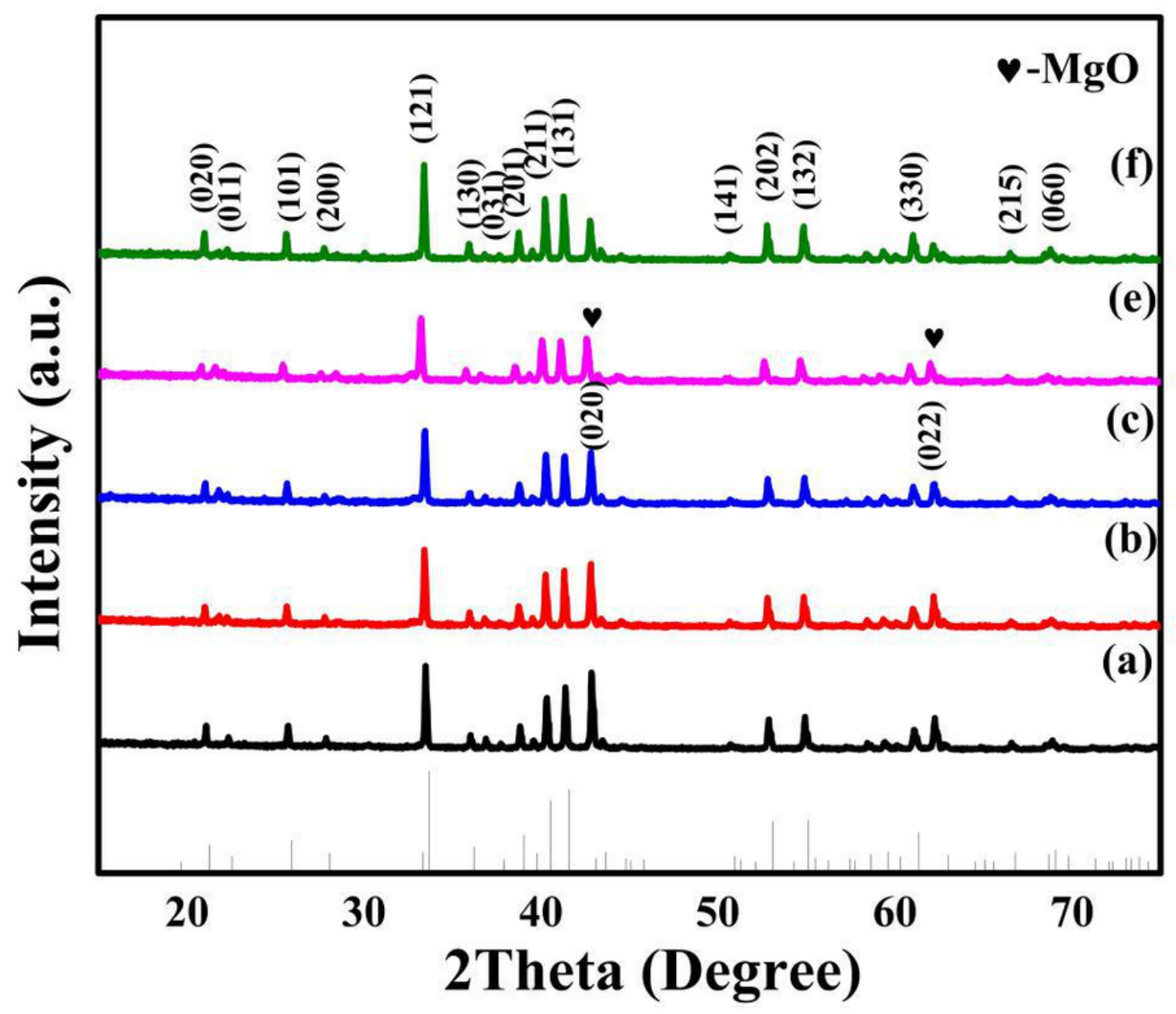

Figure 4

XRD patterns of 3MgO-B2O3-2wt\%BCB-ywt\%H3BO3 $(y=0,5,10,15$, and 20) ceramics sintered at their optimum temperatures: (a) $y=0,1050^{\circ} \mathrm{C}$, (b) $y=5,1025^{\circ} \mathrm{C}$, (c) $\mathrm{y}=10,1000^{\circ} \mathrm{C}$, (d) $\mathrm{y}=15,975^{\circ} \mathrm{C},(\mathrm{e}) \mathrm{y}=$ $20,975^{\circ} \mathrm{C}$. 

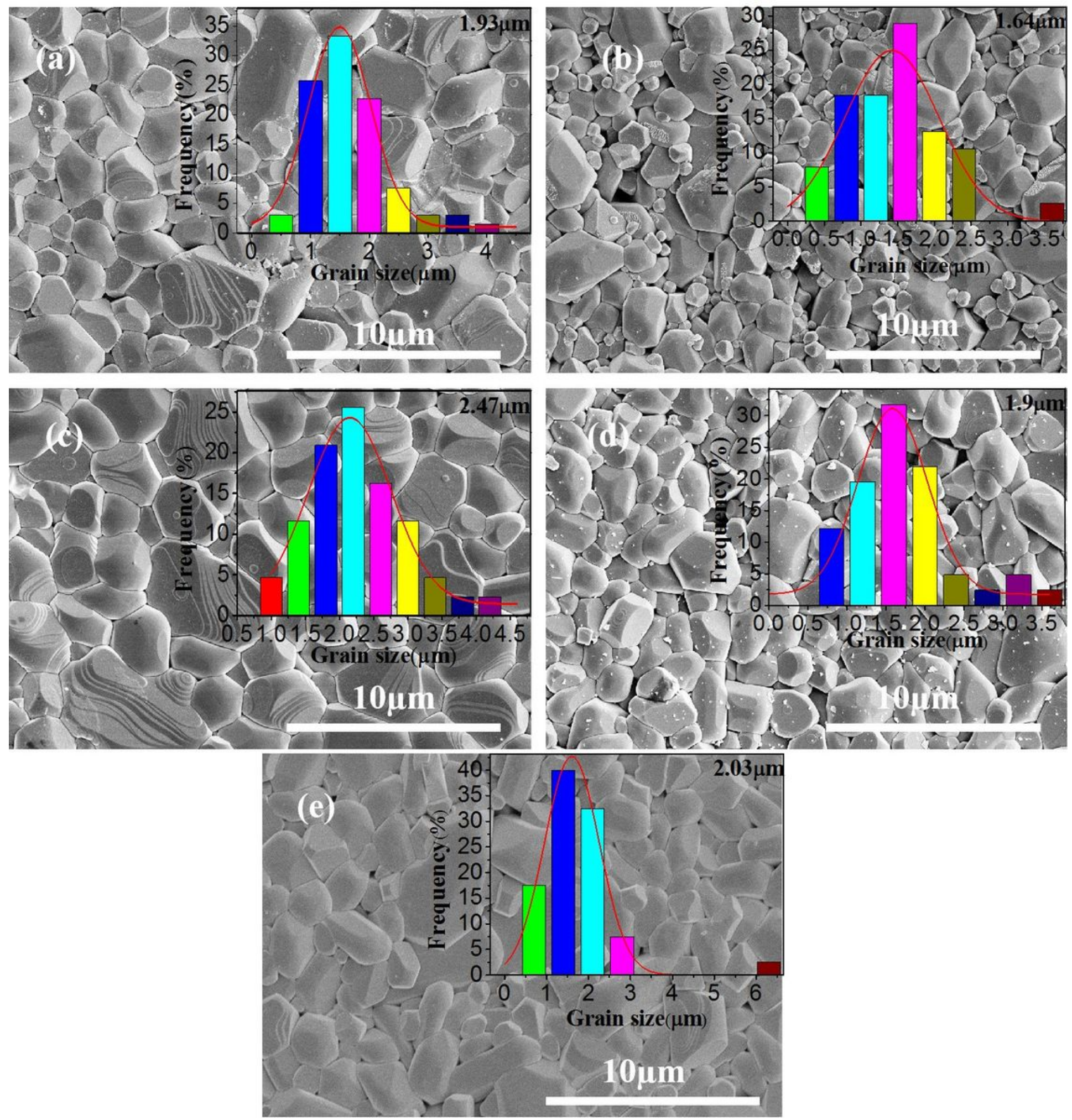

\section{Figure 5}

SEM images of 3MgO-B2O3-2wt\%BCB-ywt\%H3BO3 ( $y=0,5,10,15$, and 20$)$ ceramics sintered at their optimal temperatures: (a) $y=0,1050^{\circ} \mathrm{C}$, (b) $y=5,1025^{\circ} \mathrm{C} \otimes\left(\right.$ (c) $y=10,1000^{\circ} \mathrm{C}$, (d) $y=15,975{ }^{\circ} \mathrm{C},(e) y=$ $20,975^{\circ} \mathrm{C}$. 


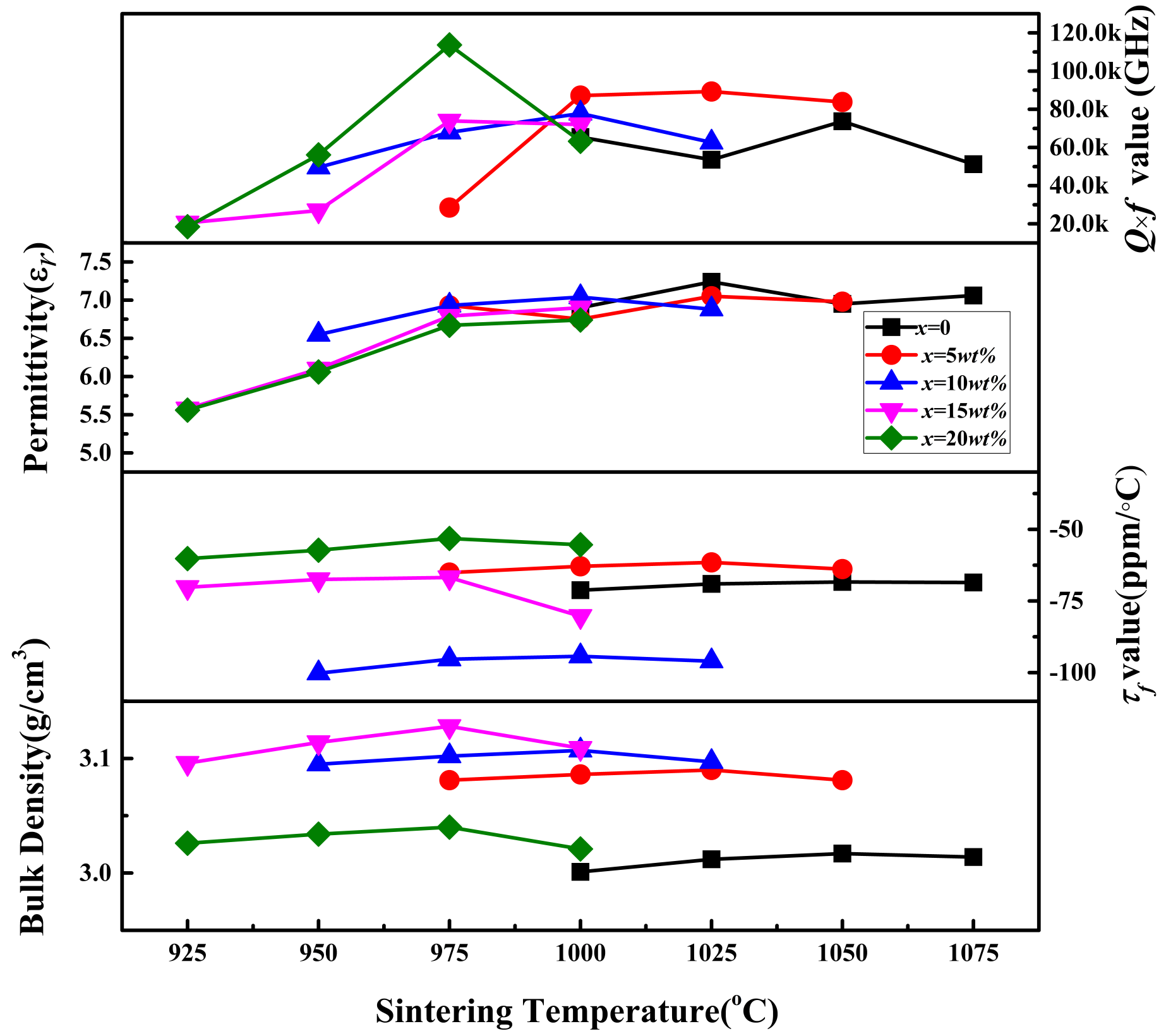

Figure 6

Bulk density, $\varepsilon r, \mathrm{Q} \times f$, and tf of 3MgO-B203-2wt\%BCB-ywt\%H3BO3 (0 $\leq \mathrm{y} \leq 20)$ ceramics sintered at optimal temperatures as a function of $y$ value. 


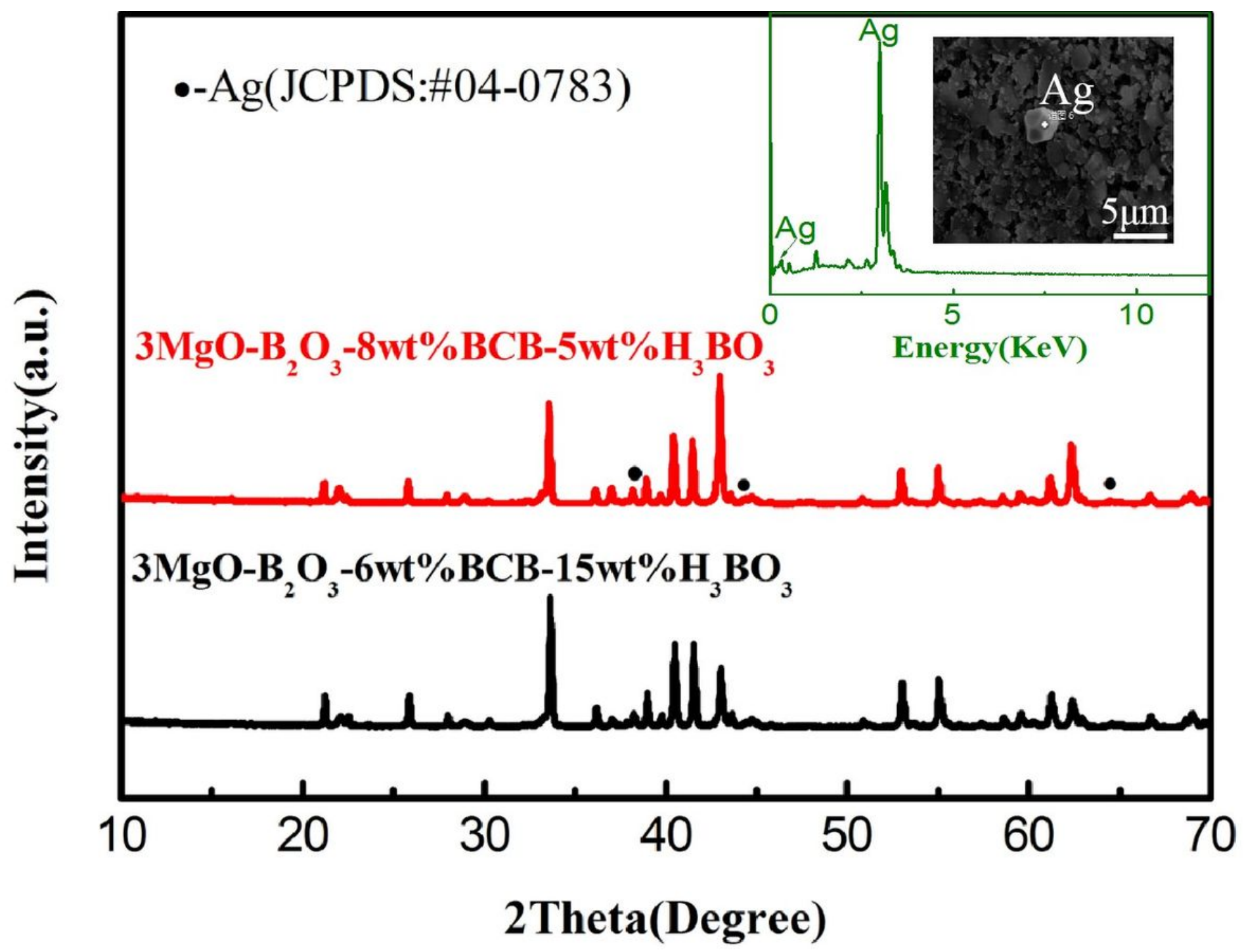

Figure 7

XRD and SEM results of 3MgO-B2O3-xwt\%BCB-ywt\%H3BO3( $(x=6,8, y=5,15)$ ceramics co-fired with silver powder (The inset shows the EDS analysis of a 3MgO-B2O3-8wt\%BCB -5wt\%H3BO3 sample co-fired with $\mathrm{Ag})$. 